\title{
柔構造複合材料
}

\section{福多 健二}

Kenji Fukuta，工業技術院 織維高分子材料研究所

\section{1.は じめに}

「柔構造」一わが国火执いても超高層ビルの並立す る光景が見られる今日，乙ばしば耳にする言葉であ

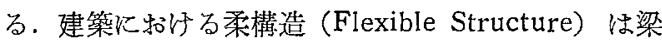
(はり)などの接合部を剛とせず，構造物の振動周期 を大きくすることにより，構造物に作用する抗力を小 さくする構造を意味し, 剛構造の対義語として用いら れている.

近年，材料の分野に括いても，大型の殼状材料な ぞ，大きな破壊強度とともに flexibility を有する材 料が多方面で要求されて和り，その性能向上が望まれ ている．本報では素材の複合化によって，上記の柔構 造（的）特性を発現させた材料を柔楧造複合材料 (Flexible-Structure Composit) と呼称し，谷の繊維 利用技術の凮辺について一，二の問題をまとめ，今後 の新材料開発の参考に供したい.

\section{2. 織維と柔構造}

従来の繊維を基材として充てんしたいわゆる FRP は「弱いプラスチックを織維で強化する」といら考え 方から，剛性のより大さな剛構造の材料を指向して発 展してさたよらである。

繊維特よびその集合体が有する高い比強度と柔軟性 は他の材料では得難い特性であり，「強くて軽いが形 態の不安定な繊維を樹脂で固めて，材料としての加工 性と操作性を付与する」ことが柔構造複合材料を設計 する上の要点である。繊維の分散状態, 組織など, 複 合化に際しての織維状基材の構成条件が材料の柔構造 （的）特性に影響を及汸す。ここでは織物を基材とし た複合材料を中心に複合化の条件と柔構造特性につい て述ベる.

\section{2-1. 系の組織による効果}

多重織物など，よこ糸との交差長を異にする数種の

Flexible-Structure Composit.
たて糸によって織成された織物では，その伸張による 糸の破断が，蛇行程度の小さい系より順次生ずるた め，織物は特異な伸張破断挙動を示す. 第 1 図に多重 織物の組織と破断挙動の相違をモデル的に示した12.

この種の材料では, 衝摮的に加えられた応力は時間 帯を持って開放されるので, 緩衝性を有し, 特異な柔 構造的性質を示す.

\section{2-2. 膜状柔構造}

従来, 単なる被覆材料として建築関係で用いられて いたキャンバス,フィルムなどが, 高強度, 耐候性の ある膜材料として開発されるに掞よび，大空間を覆う 建築構造材料に用いられてきている。この場合の膜材 料は, 引張りにだけ耐える柔材料であり，膜材料は二 方向に引張り力を与えることにより, 形態は安定し, 剛性が付与される.膜状柔構造複合(積層)材料の例と して，係留エアロスタット用の外皮材料などがある22. この種の外皮材料にはどのよらな気候条件の下に抒い ても長期間使用でさる耐久性と, 大きな有効積載荷重 を保つための軽量で強力な枋料特珄が要求されるが, これらの条件は，適切な素材の組合せと積層楧造によ って満たされている。

\section{3. 三次元織物を基材とした柔構造材料}

$X, Y, Z$ の三方向に糸やロービングを組織させた立 体状の織物 (Three-Dimentional Fabric, 以下 3-D 織物といら）を樹脂などのマトリックスと複合した瀻
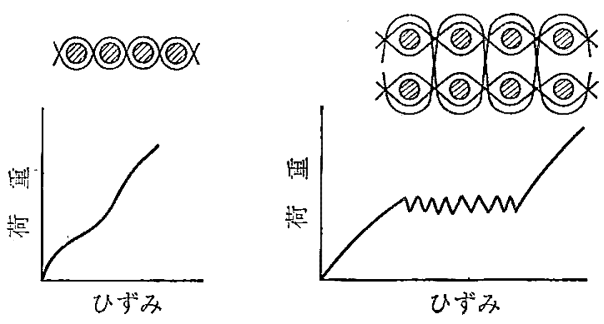

第 1 図織物組織と破壊挙動

高分子 28 巻 10 月号 (1979 年) 
維複合材料 ${ }^{3) ~(6)}$ が新しい材料として多くの分野で注目 されている，3-D織物を用いた複合材料は機械的性質 や熱的性質などて優れた材料特性とが得られる。 た，これらの性質の発現に際して，采やロービングの 種類捛よびその配列密度を変觉ることにより, 要求さ れる性能に応じて材料の等方性, 異方性を比較的容易 に得ることができ，さらに，マトリックスの充てん様 式を工夫することにより，特異な性質を誘導できる。

次に，3-D織物を構成するロービングにのみ樹脂を含 浸させ，ロービング間を空吵にすることにより, 3-D 織 物を柔構造化した材料(6)についてその概要を述べる。

\section{3-1. 3-D 織物}

従来の編織技術のみで，3-D 織物を製織することは 困難であり，3-D 織物を基材とした複合材料が沉用 の材料として活用されるためには, 能率的な $3-\mathrm{D}$ 織 物の製織機構の開発が必要でめる。

3-D 織物の組織例を第 2 図に示す。第 2-a 図はた て糸よこ糸, 垂直糸が蛇行することなく単に直交した 状態で構成された直交状織物であり，第2-る図は， 垂直糸に対するたて糸とよこ糸の位置を転位させるこ とにより，三成分の糸が通常の平面的織物之同様汇組 織された平織状織物である. 直交状の織物は糸が直線 状であるため，引張りなどの作用注して変形が少な く、また製織中の系の運動が単純であるため, 能率的 な製織が可能であるなどの特徵を有する. 平織状の織 物は形状の保持性が良好であり, 樹脂などのマトリッ クスとの複合化に際して織物の形状変化が少ないなど の特徵があるが，その製織機構は複雑となる。

平織状の 3-D 織物を能率よく製織するために，筆 者らが考案した新しい製織機構》の概要を第 3 図に示 す.

第 3 図に示す垂直糸開口装置は垂直糸列を一方向に 平行移動させる手段のみで, 垂直系に対してたて糸お よびよこ采の二成分の糸を転位ざ吼た 3-D 織物を得 るるのであり,このための系挿通用開口を垂值糸間に 形成でさるように工夫されている、第 3 - A図比い て, 垂直系 $Z$ の通采孔を有する綜絖（そらこう） 8

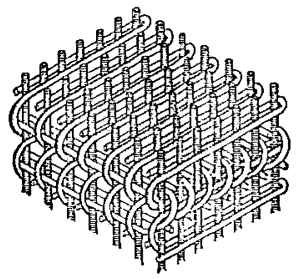

(a)

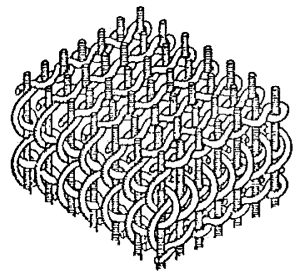

(b)
穊 2 図 3.D 織物の組織例

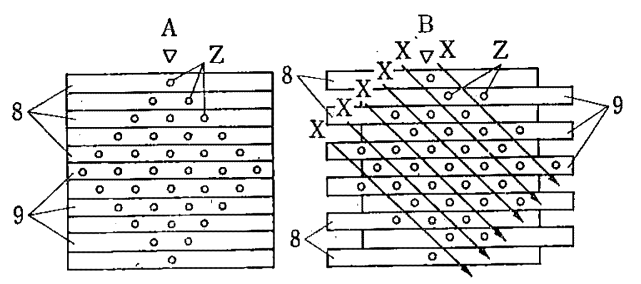

$\mathrm{C}$
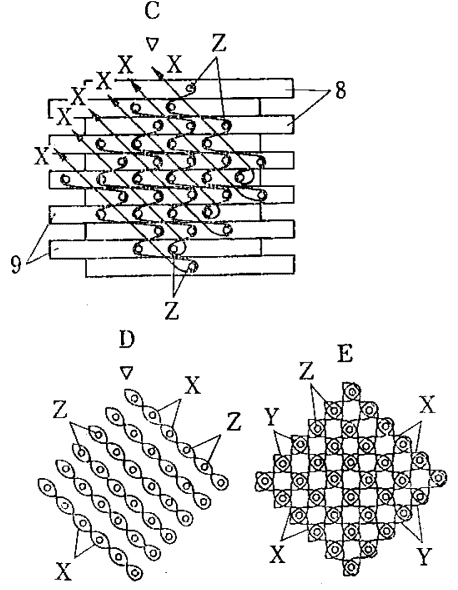

第 3 图 3-D 織物製織用の垂直糸開口法と製織順序

特よび 9 は, 基準位置を中心として通糸孔の連列の方 向に, 通系孔の単位ピッチ沉相当する距離だけ移動可

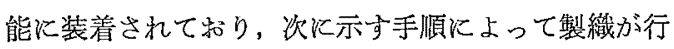
なわれる（図中、は綜絖の位置関係の理解を容易にす るために付した綜絖上の定位置を示す指標である).

[製織の順序]

(1) 必要本数の垂直系を綜絖 8 括よび 9 亿通し, 垂 下させる(第 3 - A図).

(2) 綜絖 9 を右方に 1 ピッチ移動させ, 矢印方向か らよこ糸Xを挿入する（第3-B図）：との後， 綜絖を旧位置に復帰さ世る。

(3) 綜絖 8 を右方に 1 ピッチだけ移動し，上こ糸X を矢印の方向活入する (第 $3-C$ 図). その後, 綜絖 8 を旧位置に復帰する(第 3 -D図).

(4) 綜絖 9 を左方へ 1 ピッチ移動させ, よこ糸 $X$

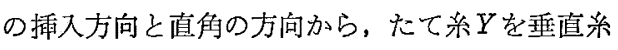
$Z$ の各列間の開口飞挿入. 綜絖 9 を旧位置へ復㷌.

(5) 綜絖 8 を左方に移動させ，たて糸 $Y$ 垂直糸 $Z$ の各列間へ插入. 綜絖 8 を旧位置へ復帰（第 3 $\mathrm{E}$ 図).

\section{3-2. 3-D 織物を用いた柔構造材料の機械的性質}

3-D 織物を構成するロービングに樹脂を含浸させ， ロービング間の空隙が多孔部分となるように成形を行

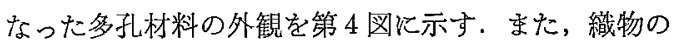
諸元を第 1 表䏡す. 表中の $Z_{x}$ は $Z$ 糸の $x$ 方向の口 ービング配列ピッチであり， $Z_{y}$ は $Z$ 系の $y$ 方向の口 


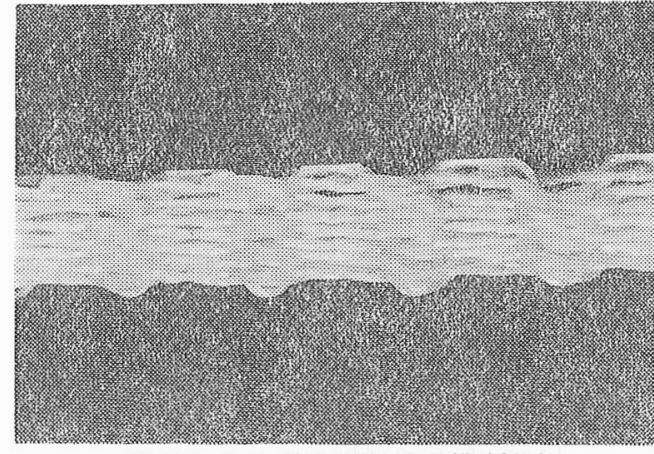

第 4 図 3-D 織物を用いた柔構造材料 （多孔）の外観図

ービング配列ピッチを意味する，記号０は樹脂（エポ キシ樹脂）のみの試料を示す.

第 5 図に，ロービングの配列密度を異にする多孔型 材料と, 上記と同じ組織の基材に樹脂を完全に充てえ した従来法による全充てん型材料の比曲げ応力ーひず み線図の比較例を示す。

全充てん型の材料は降伏点に近い負荷によって破壊 を生じ, 材料の一部は欠損する. 多孔型の材料は大き な比曲げ強力, 比曲げ弾性率を示す。この材料はロー ビングが交差する位置で破壊が生じても，その組織点 で破壊の進行が妨げられ, 次の組織点が破壊するま で，負荷に耐えることができる．また，多孔型材料は 全充てん型材料の降伏点に相当する負荷のもとでも破 壊の発生はなく, 完全な変形回復能を有し, 繰返して 負荷を加えることができるなど，柔構造材料としての 特性を示す.

3-D 織物を用いた多孔型材料の圧縮変形の模型を第 6 図に示す．圧縮方向に配列する部材の一単位長につ
第 1 表 三次元織物の諸元

\begin{tabular}{|c|c|c|c|c|}
\hline \multirow{2}{*}{ 記号 } & \multirow{2}{*}{ 基材の組織 } & \multicolumn{3}{|c|}{ 糸の配列ピッチ（mm) } \\
\hline & & $Z_{x} \quad Z_{y}$ & $X_{y} \quad X_{z}$ & $Y_{x} \quad Y_{z}$ \\
\hline 0 & $Z$ & - & 一 & 一 \\
\hline 1 & 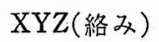 & $2.8 \times 2.8$ & 一 & - \\
\hline 2 & 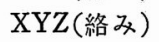 & " & $2.8 \times 50$ & $2.8 \times 50$ \\
\hline 3 & 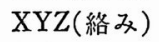 & " & $2.8 \times 30$ & $2.8 \times 30$ \\
\hline 4 & 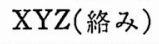 & " & $2.8 \times 15$ & $2.8 \times 15$ \\
\hline
\end{tabular}

いての圧縮挙動は, 第 7 図に示す線状体の座屈模型に 近似でき, 一単位長に相当するロービング複合材につ いての荷重 $W_{k}$ と舺位長さ $l$ との関係は Euler の 式 ${ }^{8)}$ か次式で示される.

$$
W_{k}=\frac{n^{2} \pi^{2} E_{b} I}{l^{2}}
$$

ここで, $d:$ ロービング複合材の直径, $E_{b}$ : 曲げ 弾性定数, $I$ : 断面慣性モーメント, $n$ : 端末の条件 による係数.

上式から座屈強度はロービング複合材の単位長の 2 乘に反比例することが予測される．圧縮荷重の方向と 直角方向の部材の配列間隔は上式の $l$ の值を定めるこ とになり，材料の王縮挙動に関与する重要な值とな る.第 8 図にねじり試験を行なった後の材料の外観を 示すａ（図は多孔型材料であり，繰返して大きなねじ り变形（ひずみ量 $5 \%$ ）を与兄ても材料の損傷は見受 けられない. b 図は全充てん型の材料であり,ひずみ 量 $5 \%$ の 回の変形で材料は破壞する.

\section{3-3. 3-D 織物を用いた柔構造材料の用途}

従来より，多用されている㵶維強化複合材料は多孔 性を有していないのが通例であり，そ机が多孔性を有 しているとしても, マトリックス中にランダムな大き さと配列で介在する多数の気泡による空隙を備えた構

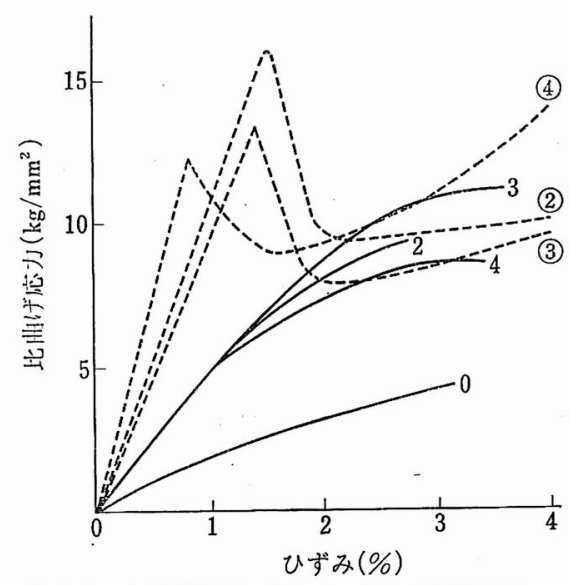

(2)(3)(4): 多孔型材料, 234 : 全充てん型材料 第 5 図 3-D 織物を基材とした複合材料の比曲げ 応力-ひずみ線図
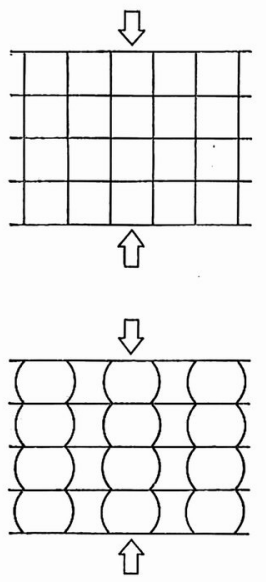

第 6 図 3-D 組織体の 圧縮模型

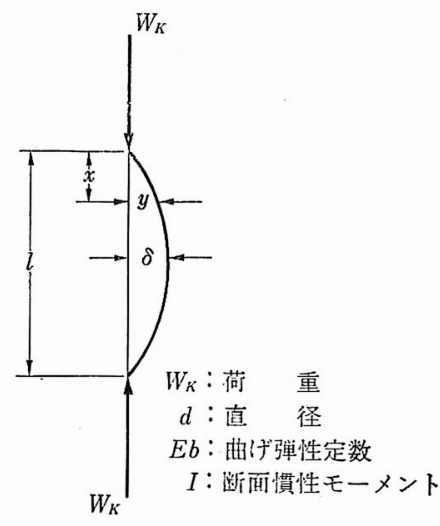

第 7 図 線状体の座屈模型

高分子 28 巻 10 月号 (1979 年) 


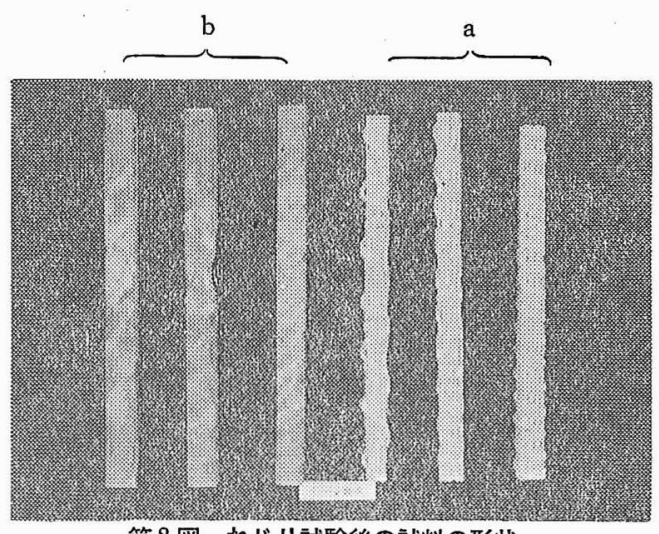

第 8 図 ねじり試験後の試料の形状

造のものであった３-D 織物を用いた多孔材料は， 織物を構成する糸やロービングにのみマトリックスと なる素材を含浸させて, 規則正しい立体格子状の多孔 複合構造を形成させたものであり，特に繰返し荷重に 対する大さい強度を有するとともに空隙率が極めて大 きい軽量な柔構造的材料特性を示す.

比強度, 比剛性の大きなことの特徴は, 軽量化を必 要とする航空機用部材に広く生かすことができよう。

例穵ば, Landing gear door, Speed Brake などの可 動部品の他, 床パネル，ドア，隔壁などの内装材料と しての利用がある。

弾性を暴にする $X, Y, Z$ 成分の素材を用いて，大 きな衝撃吸収能を有する 3-D 複合材料を設計するこ とができる，これらの高衝撃吸収材料は，軽量化とパ ンクレスの特殊構造を生かして車輪などへの応用が考 えられている、またこの種の高衙揧吸収材料は高速車 体の緊急用制動材料としての応用が注目されている. これらの材料の開発により, 関連分野の軽量化や安全 性に奇与することができよう。これらの柔構造的特性 は海洋の分野に新いては防舷材, 船体用構造材として の応用が考えられる。

また，3-D 織物複合材料は軽量性を生かした, 住宅 用軽量パネル, 海洋浮力材などへの応用がある.さら に連通した空吵を生かした住宅用通風材料や，土木用 水抜き材料などとしての活用が考えられる。

\section{4. おわりに}

以上, 今後の材料の発展の中で, 重要な役割を果た
すことが予測される柔構造材料について, 特に, 3-D 織物を用いた複合材料に焦点を置いて, 材料特性とそ の応用の展望を行なった。

これらの材料性 3-D 織物の製織技術で代表される ように, 織維加工技術との接点の大きな分野である. この種の技術に関連して, 球殼状や円錘台状など立体 的で比較的に大型の賦形物の織物を製織する新しい技 術の開発が進められている。この材料は裁断や縫合の 手段を用いずに, 織物の表面の輪郭や厚さ変化执よび 組織（多層または三次元）の变化を製織中の糸長や系 密度, 組織法を調整して織り上げたフルファッション 的構造体である.これに樹脂などのマトリックス材を コーティングまたは含浸した複合材料は, 機械的, 熱 的外力によるひずみが小さく，また，縫合や接合部を 有しないために構造物としての欠陥部がなく，過酷な 負荷条件のるとでの物性に対する信頼度が大きいなど の特徵を有している.

複合材料の最近の発展ほめざましく，その用途はま すます拡大し, そして, 繊維加工技術との関連はさら に大きくなってきている、ここで取り上げた幾つかの 縉維に関する問題も, 今後, 複合化の技術との接点を 広げていくものと思われる。

繊維加工技術が科学の速い進歩と常に同居している といら認識と, 繊維加工の周辺技術の環をより大きく 広げていくことが重要であるといらことから, 内容が トピック的なものに偏向したようである.

な和参考資料を付記するととるに，関係諸氏に感謝 を申し上げる。

\section{文献}

1) 山下重二 : 第 5 回繊維工学研究討論会, 蟣維機械 学会 (1976)

2) L. B. Keen : J. Coated Fabrics, 5 [7] (1975)

3) R. M. Lurie: Applied Polymer Symposium, 15, 103 (1970)

4) M.L. Yaffee: Aviation Week \& Space Technology, May, 27 (1968)

5) 福多健二ら：絾高研研究発表会資料（1974）

6) 福多健二ら：同上, (1979)

7）福多健二, 青木栄次:三次元織物製織機に拈ける たて䒺開口方法, 特願昭 54-39225

8）例光ば，清水篤璴 : 材料力学, 共立出版 p. 168 